\title{
A typology for catalyzing pedagogical change: Fostering multiple pathways through SoTL
}

\author{
DEANDRA LITTLE ${ }^{1}\left(\mathbb{D}\right.$ and JESSIE L. MOORE ${ }^{2 *}$
}

\author{
${ }^{1}$ Center for Advancement of Teaching and Learning, Elon University, Elon, NC, United States \\ ${ }^{2}$ Center for Engaged Learning, Elon University, Elon, NC, United States
}

\section{THEMATIC ARTICLE}

Received: October 1, 2020 • Accepted: June 14, 2021

Published online: July 30, 2021

(C) 2021 The Author(s)

\begin{abstract}
Building on ecosystem models that examine individuals' development within professional environments (Roxå, 2014; Hannah \& Lester, 2009), we explore how campus centers for educational development and research can provide a range of experiences for faculty to learn about scholarship of teaching and learning (SoTL), conduct individual or collaborative - and sometimes multi-institutional - SoTL, and go public with their work. Using extended case studies of colleagues who have become increasingly more active in SoTL, we created a typology of the experiences that supported their development. The case studies illustrate that offering a variety of educational development options at different institutional levels and with different time commitments enables developers to meet faculty where they are - and to provide growth opportunities for deepening SoTL commitments. Our typology can help educational developers prioritize among potential programs by considering the cost-benefit analysis not only for individual faculty but also for micro-, meso-, and macro-level institutional cultures.
\end{abstract}

\section{KEYWORDS}

educational development, professional development, college faculty, scholarship of teaching and learning, pedagogical change, ecosystem model, case studies

\footnotetext{
*Corresponding author. E-mail: jmoore28@elon.edu
} 


\section{INTRODUCTION}

Using illustrative case studies from our institution, we examine how colleges and universities can develop pathways to and through the scholarship of teaching and learning (SoTL) so that faculty can contribute both to pedagogical change and to research about it. We build on ecosystem models, which examine individuals' development in relation to their professional environment (Hannah \& Lester, 2009; Roxå, 2014). Our pilot study uses illustrative case studies of individual faculty to explore how campus ecosystems provide experiences at multiple levels and depths through which faculty learn about SoTL and conduct SoTL projects. We offer an emerging typology of experiences that support this educational development. Unique pathway combinations vary by faculty goals and career stages, but viewed within the typology, we gain new appreciation for how educational development programs support faculty's professional trajectories.

We focus on SoTL because it can catalyze pedagogical change. When faculty study what works in their teaching and how their instructional choices inform student learning, they often use the inquiry results to adapt their future teaching - not only in the specific course they studied, but also across their teaching portfolio (Bernstein, 2013). Their individual SoTL work also supports broader pedagogical change within their institutions, as Bernstein (2013, p. 36) reflects:

Since their teaching and their students' learning are typically well documented and often publicly visible, SoTL-active faculty members provide an accessible model of excellence in instructional design and reflective practice. It can be easier to create new variations of teaching if there are visible examples that demonstrate concretely what innovations look like and how they function.

Providing educational development focused on SoTL supports broader institutional goals for pedagogical change. In this study, we sought to understand and categorize which specific educational development opportunities faculty colleagues had used to advance their SoTL activity.

Viewed through the lens of our emerging typology, the case studies in our pilot suggest that faculty develop more individually tailored SoTL identities when they have access to unique pathways through educational development experiences that reflect a range of formats and timecommitments. This typology also emphasizes how multiple programs within a campus ecosystem can act as catalysts for pedagogical change at different levels and career stages. It captures factors that might:

- influence where colleagues start, continue, or deepen their individual SoTL work;

- vary in scale and scope; and

- function as entry points to SoTL, to engaging with others in it, or to leading new efforts at departmental, institutional, or multi-institutional levels.

We argue that this intentionality and our across-campus partnerships facilitate faculty members' development of significant networks (Roxå \& Mårtensson, 2009; Poole, Iqbaul, \& Verwood, 2019) that ultimately catalyze pedagogical change over time by helping faculty situate their own professional development as teacher-scholars within the institution's systems (Bond \& Blevins, 2020). We hope that others will adapt the typology to their own institutions to identify and extend potential pathways to and through SoTL. 


\section{BIOECOLOGICAL MODELS TO FRAME MAPPING PROJECTS}

Bronfenbrenner and colleagues described the bioecological model as "an evolving theoretical system for the scientific study of human development over time" (Bronfenbrenner \& Morris, 2006, p. 793). Bronfenbrenner's model also situates this development in relation to individuals' interactions with their environments:

- The microsystem - their immediate environment,

- The mesosystem - interrelated settings in which they become an active participant (e.g., home and work),

- The exosystem - proximal settings they don't directly interact with but that may impact them, and

- The macrosystem - consistencies or patterns that carry across the micro-, meso-, and exosystems and "any belief systems or ideology underlying such consistencies" (Bronfenbrenner, 1981, p. 258; see also Bronfenbrenner, 1993).

Separately, organizational learning scholars developed a multilevel model that also uses micro, meso, and macro descriptors without explicitly drawing from the Bronfenbrenner model. Hannah and Lester (2009) theorize a "multi-level approach to learning where top-down leadership serves to set the conditions to maximize the emergence of knowledge creation and diffusion, while limiting leader intrusion into the actual creative process" (p. 35). Their model examines interventions leaders can make with individual followers (micro), within social networks (meso), and at the systems level (macro). This model informs educational development studies (e.g., Roxå \& Mårtensson, 2012; Mårtensson, Roxå, \& Stensaker, 2014; Roxå, 2014) in which the micro level is commonly considered the department level. Understanding educational development as an ecosystem can help us understand models of pedagogical change that account for activities across levels within a university.

To categorize the different ways faculty navigate this ecosystem of support, we built a typology on the bioecological and organizational learning models and focused on extended case studies of colleagues who have become increasingly more active in SoTL. Drawing on these models for our mapping supported our goal to explore how the campus centers; we direct and our partners across the university provide a range of experiences for faculty to learn about SoTL, conduct individual or collaborative SoTL, and go public with their work. As in the organizational learning model, we use micro to describe interventions at the department level, whichadapting from the bioecological model-could be considered faculty's immediate environment. We use meso to describe interventions in the networks and linkages between microsystems, and we use macro to describe work at the systems level (à la organizational learning) that also may reflect underlying, system-wide beliefs and ideologies (à la the bioecological model). Like Weston et al. (2008), Friberg (2016), Simmons (2016, 2020), and other SoTL scholars, we add a mega level to capture experiences that extend beyond our own university.

Our adaptation uses these levels to metaphorically or figuratively understand relationships among educational development interventions in these different spheres. In our pilot study, we reviewed the CVs of three faculties who steadily have increased their SoTL activity during their careers at the university. Noting their experiences ranged in time and investment-consistent with research on educational development's impact (Chism, Holley, \& Harris, 2012)—we added dimensions to the typology identifying activities as one-time, low investment; moderate 
investment; or multi-semester, high investment. Next, we inventoried the activities they had undertaken, ranging from reading groups to short-term grant-funded projects to longer-term research or educational development commitments. We classified each opportunity as occurring at the micro, meso, macro, or mega level and categorized the level of investment each required. Using this emerging typology, we then mapped the three colleagues' activities over time to examine their individual educational development pathways. After completing a draft typology from our case studies, we tested whether we could use the typology to describe pathways to and through SoTL taken by other university colleagues. In what follows, we share the emerging typology, illustrate three pathways, and discuss how other institutions might use the typology.

\section{A CASE STUDY: MAPPING PATHWAYS TO AND THROUGH SOTL}

Given a bioecological model's attention to micro, meso, and macro activity unique to the setting, this type of mapping is necessarily bound to the local institutional context. Therefore, we begin this section with an introduction to our own institutional context before sharing our sample mappings. We hope that our example prompts others to replicate the process in their own institutions; a critical mass of examples from different institutions could highlight shared, generalizable characteristics. Even without that critical mass, the activity can help educational developers take stock of the pathways their local opportunities foster.

\section{Our institutional context}

Located in the southeastern US, our institution is a privately funded, liberal arts university, which primarily focuses on undergraduate teaching, enrolling approximately 6,500 undergraduate students and 800 graduate and professional students. The university mission prioritizes teaching while also supporting faculty scholarship and mentoring. The faculty evaluation and promotion process is guided by documents that describe a range of valued forms of faculty scholarship aligned with Boyer's (1990) broadened definition of academic research, including the scholarships of teaching and learning, application, and integration in addition to research of discovery.

To support deep, scholarly explorations of teaching and learning, the institution invests in multiple educational development supports. Faculty engage in, develop, and then lead faculty development efforts for teaching and learning, including for specialized topics, such as servicelearning or study abroad pedagogies. Supports include short- and long-term workshops, internal grants that support SoTL conference travel or SoTL projects, faculty learning communities focused on specific teaching methods or pedagogies, and leadership positions as Faculty Fellows, Center Scholars, or Associate Directors, for which faculty receive course release time in order to foster programming for colleagues.

Founded in 2005, the Center for the Advancement of Teaching and Learning (CATL) provides a range of educational development programming for faculty and contributes to university initiatives for teaching and learning or faculty mentoring. The Center staff includes full-time educational developers and faculty leaders who typically serve four-year terms. The Center develops resources to further effective, evidence-based, and inclusive teaching and learning practices, as well as provides funding and scaffolded support for SoTL projects and publications through workshops, learning communities, individual consultations, grants, and 
fellowships, including a multiyear fellowship to support a SoTL project. These programs range in time commitments, level of involvement, and level of impact.

The Center for Engaged Learning (CEL), a separate center, launched in 2012 to foster international research on central questions about student learning in higher education. Most CEL programs foster multi-institutional SoTL collaborations, but CEL also shares engaged learning research with our campus to inform local teaching and mentoring. Faculty can participate in CEL reading groups, a CEL Scholar position to deepen scholarly activity on an engaged learning topic, or international and multi-disciplinary research seminars, in which teams collaborate on multi-institutional SoTL projects over three years.

\section{Mapping the cases}

Table 1 shares our emerging typology, describing the types of activities our colleagues have undertaken as they have started, continued, or deepened SoTL work. As we illustrate in the brief case studies that follow, this typology highlights our campus's intentionality of having multiple programs that act as catalysts for pedagogical change at different levels within our campus ecosystem and at different career stages.

Professor A has participated in multiple initiatives in both centers, often demonstrating intensive engagement across micro, meso, macro, and mega levels (see Fig. 1). During her early years at the university, Professor A focused on projects related to teaching in her department (Micro; Low-Moderate-High), but she sought resources beyond her department to support her work. For example, she participated in CATL's Faculty Writing Residency (Macro; Moderate) to go public with her innovative approaches to teaching writing in her department's courses. She then was awarded a two-year CATL Scholar award (Macro; High); participated in a multiinstitutional CEL research seminar (Mega; High); and participated again in CATL's Faculty Writing Residency (Macro; Moderate).

Subsequently, Professor A used CATL travel grants to attend external pedagogy seminars (Mega; Low) while also participating in workshops co-sponsored by CATL and partners (Meso; Low) and collaborating on multi-institutional grant-funded research (Mega; High). She joined an international collaborative writing group (Mega; Moderate). Most recently, Professor A completed a two-year CEL Scholar role (Macro; High), which gave her opportunities to facilitate CEL reading groups (Macro; Low) and prompted her to apply for a CATL grant to pilot a pedagogy project (Meso; High).

Although Fig. 1 likely oversimplifies Professor A's pathways as she has moved among levels and time commitments, the image illustrates that her activity has shifted towards higher degrees of investment, often at higher levels in the university's bioecological system. Circles in the figure mark ongoing and deepening commitments to SoTL or pedagogical change.

Similarly, Professor B has engaged across levels and time commitments (see Fig. 2). In addition to sustained participation in department pedagogy initiatives, including an ongoing research group (Micro; High), Professor B used a CATL grant for course redesign (Macro; Moderate) early in her career. She subsequently was awarded a two-year CATL Scholar award (Macro; High) and used a partner program's summer grant to focus on writing instruction in department-level courses (Meso; Moderate). She served on school-level (Meso; High) and university-wide (Macro; High) curriculum committees.

Professor B collaborated on multi-institutional grant-funded research (Mega; High) before completing a multi-year term as an Associate Director of CATL (Macro; High), which extended 
Table 1. Typology of pathways to and through SoTL

\begin{tabular}{|c|c|c|c|}
\hline & $\begin{array}{l}\text { Low Investment } \\
\text { One-time activity } \\
\text { (e.g., Microtime) }\end{array}$ & $\begin{array}{l}\text { Moderate Investment } \\
\text { Limited-term } \\
\text { (1 week, } 1 \text { semester) } \\
\text { (e.g., Mesotime) }\end{array}$ & $\begin{array}{l}\text { High Investment } \\
\text { Multi-semester } \\
\text { (e.g., Macrotime) }\end{array}$ \\
\hline $\begin{array}{l}\text { Micro } \\
\text { Department/ } \\
\text { Academic Unit }\end{array}$ & $\begin{array}{l}\text { Department Reading } \\
\text { Group; Department } \\
\text { SoTL Workshop }\end{array}$ & $\begin{array}{c}\text { Department Course } \\
\text { Redesign; Department } \\
\text { Pedagogy or Assessment } \\
\text { Committees }\end{array}$ & $\begin{array}{l}\text { Ongoing Department } \\
\text { Research Group on } \\
\text { Curriculum and } \\
\text { Pedagogy }\end{array}$ \\
\hline $\begin{array}{l}\text { Meso } \\
\text { Linkage between } \\
\text { microsystems, e.g., } \\
\text { Curriculum, cross- } \\
\text { departmental or } \\
\text { cross-school } \\
\text { collaborations, } \\
\text { programs of study }\end{array}$ & $\begin{array}{c}\text { CATL/Partner } \\
\text { Workshop }\end{array}$ & $\begin{array}{l}\text { Partner Summer Grant; } \\
\text { School-Level Teacher- } \\
\text { Scholar Committee; } \\
\text { Communities of } \\
\text { Practice }\end{array}$ & $\begin{array}{l}\text { CATL Grant for Pilot } \\
\text { Pedagogy Project; } \\
\text { Service on School-Level } \\
\text { Curriculum Committees }\end{array}$ \\
\hline $\begin{array}{l}\text { Macro } \\
\text { University Resources, } \\
\text { Programs, } \\
\text { governance structures }\end{array}$ & $\begin{array}{l}\text { CATL Reading Group; } \\
\text { CEL Reading Group; } \\
\text { SoTL showcase }\end{array}$ & $\begin{array}{l}\text { CATL Writing } \\
\text { Residency; CATL Grant } \\
\text { for Course Redesign; } \\
\text { CATL Programs } \\
\text { (Facilitator); CATL } \\
\text { Advisory Committee; } \\
\text { Experiential Learning } \\
\text { Advisory Committees; } \\
\text { Communities of } \\
\text { Practice }\end{array}$ & $\begin{array}{l}\text { CATL Scholar; CEL } \\
\text { Scholar; } \\
\text { CATL Associate } \\
\text { Director; Experiential } \\
\text { Learning Fellow; } \\
\text { University Committees } \\
\text { or Working Groups } \\
\text { focused on Pedagogy or } \\
\text { Teaching; University- } \\
\text { Sponsored Pilot } \\
\text { Pedagogy Project }\end{array}$ \\
\hline $\begin{array}{l}\text { Mega } \\
\text { Beyond the university: } \\
\text { Multi-institutional } \\
\text { work, Professional } \\
\text { organizations, } \\
\text { Granting agencies, } \\
\text { etc. }\end{array}$ & $\begin{array}{c}\text { External } \\
\text { Pedagogy Seminar; } \\
\text { CATL Conference } \\
\text { Travel Reimbursement } \\
\text { Grant }\end{array}$ & $\begin{array}{l}\text { International } \\
\text { Collaborative Writing } \\
\text { Group (Participant; } \\
\text { Facilitator); ISSOTL } \\
\text { Committee Member }\end{array}$ & $\begin{array}{c}\text { Multi- } \\
\text { institutional, Grant- } \\
\text { funded Research; CEL } \\
\text { Multi-institutional } \\
\text { Research Seminar }\end{array}$ \\
\hline
\end{tabular}

opportunities to facilitate departmental workshops (Micro; Low to Moderate) and a SoTL community of practice (Macro; Moderate). Most recently, Professor B moved into a leadership role for assessing the university's general education curriculum (Macro; High). Again, circles in the figure mark ongoing and deepening commitments to SoTL or pedagogical change.

Professor B's experience suggests that faculty can move among levels of access/impact and involvement throughout their career. Her involvement started with more moderate-to highinvestment activities at the macro-level, but included micro-, meso-, and mega-level activities scattered throughout. Her early activities were funded at the macro-level but focused on an 


\begin{tabular}{|l|l|l|l|}
\hline & $\begin{array}{l}\text { Low Investment } \\
\text { One-time activity }\end{array}$ & $\begin{array}{l}\text { Moderate Investment } \\
\text { Limited-term } \\
\text { (1 week, 1 semester) } \\
\text { (e.g., Mesotime) }\end{array}$ & $\begin{array}{l}\text { High Investment } \\
\text { Multi-semester }\end{array}$ \\
\hline (e.g., Macrotime)
\end{tabular}

Professor A

Fig. 1. Professor A's pathway

individual course. Her pathway indicates that as her career advanced, she became more involved in collaborations and partnership -in her teaching, her publications and presentations, and her work supporting other faculty in educational development and SoTL efforts.

Professor C joined the university after participating in extensive SoTL-focused educational development at a previous institution. Within a year, he was awarded a two-year CATL Scholar award (Macro; High) and served on a school-level teacher-scholar committee (Meso; Moderate). He subsequently completed a one-year pedagogy scholar opportunity facilitated by an experiential learning partner program (Macro; Moderate) before advancing to a research scholar opportunity facilitated by the same program (Macro; High) and serving on multiple advisory committees for experiential learning partners (Macro; Moderate). He also served on school-level 


\begin{tabular}{|l|l|l|l|}
\hline & $\begin{array}{l}\text { Low Investment } \\
\text { One-time activity }\end{array}$ & $\begin{array}{l}\text { Moderate Investment } \\
\text { Limited-term } \\
(1 \text { week, 1 semester) } \\
\text { (e.g., Mesotime) }\end{array}$ & $\begin{array}{l}\text { High Investment } \\
\text { Multi-semester }\end{array}$ \\
\hline (e.g., Macrotime)
\end{tabular}

Professor B

Fig. 2. Professor B's pathway

curriculum committees (Meso; High) and university-wide committees focused on pedagogy or teaching (Macro; High).

Over time, Professor C deepened his involvement in an international SoTL organization (Mega; Moderate), participating in and then facilitating international collaborative writing groups and serving on the organization's committees. He undertook a two-year CEL Scholar role (Macro; High) and recently started a multi-year role as an experiential learning fellow for a campus partner (Macro; High). In these roles, he has developed resource materials and facilitated academic development for other colleagues. He also serves on CATL's advisory committee (Macro; Moderate).

Professor C's pathway (Fig. 3) demonstrates the importance of offering opportunities that act as catalysts for pedagogical change at different levels within a campus ecosystem and for 


\begin{tabular}{|l|l|l|l|}
\hline & $\begin{array}{l}\text { Low Investment } \\
\text { One-time activity }\end{array}$ & $\begin{array}{l}\text { Moderate Investment } \\
\text { Limited-term } \\
\text { (1 week, 1 semester) } \\
\text { (e.g., Mesotime) }\end{array}$ & $\begin{array}{l}\text { High Investment } \\
\text { Multi-semester }\end{array}$ \\
\hline (e.g.g., Microtime) & Macrotime) \\
\hline $\begin{array}{l}\text { Micro } \\
\text { Department / } \\
\text { Academic Unit }\end{array}$ & & & \\
\hline $\begin{array}{l}\text { Meso } \\
\text { Linkage between } \\
\text { microsystems, e.g., } \\
\text { Curriculum, cross- } \\
\text { departmental or cross- } \\
\text { school collaborations, } \\
\text { programs of study }\end{array}$ & & & \\
\hline $\begin{array}{l}\text { Macro } \\
\text { University Resources, } \\
\text { Programs, governance } \\
\text { structures }\end{array}$ & & & \\
\hline $\begin{array}{l}\text { Mega } \\
\text { Beyond the university: } \\
\text { Multi-institutional work, } \\
\text { Professional } \\
\text { organizations, Granting } \\
\text { agencies, etc. }\end{array}$ & & & \\
\hline
\end{tabular}

Professor $\mathrm{C} \quad \ldots+\ldots \ldots$

Fig. 3. Professor C's pathway

different career stages. Professor C entered the institution with an extensive SoTL background, so entry-level programs were less appealing to him than opportunities to deepen his commitment to SoTL and associated pedagogical change at the meso, macro, and mega levels.

\section{DISCUSSION AND IMPLICATIONS}

While we developed this typology based on examples from a university that embeds support for SoTL throughout the institution's systems, we believe the case studies and typology suggest educational development implications that other institutions can consider. First, as our case studies highlight, offering a variety of educational development options at different levels and 
with different time commitments enables developers to meet faculty where they are-and to provide growth opportunities for deepening SoTL commitments. Although educational developers often must prioritize among programs and opportunities based on capacity constraints (e.g., budget, available time, etc.), some efforts are flexible enough to support SoTL work at different levels. For example, CATL grants have facilitated Meso-High activities by mid-career faculty and Macro-Moderate activities by new faculty colleagues. Our analysis helped us categorize educational development opportunities in new ways and to see relationships among the supports offered by different units as they played out across cases. We encourage educational developers to consider which of their programs similarly support faculty at different institutional levels and career stages.

Our pilot study revealed macro-level activities often led to additional activities at the meso and micro levels. Our case study faculty members' CATL grants, CATL Scholar research, and CEL Scholar projects have driven pedagogical change in individual courses and department curricula. Others have served as catalysts for pilot programs with faculty from multiple departments, which leads to our next observation.

Some activities do more to build significant networks (Roxå \& Mårtensson, 2009; Poole et al., 2019), which can extend capacity to foster pedagogical change. CEL Scholars, CATL Assistant Directors, and campus partners' fellows have facilitated reading groups, workshops, and communities of practice as they deepened their SoTL work. Therefore, educational developers conducting a cost-benefit analysis of potential programs should factor in carry-forward benefits that may positively impact micro-, meso-, and macro-level cultures in support of SoTL and pedagogical change.

We hope others will adapt our emerging typology in their own contexts, using an analysis of faculty CVs or interviews to complete similar mapping activities. Further research at other institutions and with a broader range of faculty could reveal other patterns in pathways to SoTL that could inform local decisions for prioritizing types of support. We also anticipate that faculty could use this typology to explore their own pathways and to guide their future educational development decisions.

\section{ABOUT THE AUTHORS}

Deandra Little is an assistant provost, director of the Center for the Advancement of Teaching and Learning, and professor of English at Elon University. Her scholarship focuses on educational development in higher education, the scholarship of teaching and learning, and teaching with images. Deandra is a former Vice President of the International Consortium of Educational Development (2017-2020) and a former president of the POD Network in Higher Education, the North American association for university teaching and learning centers.

Jessie L. Moore is director of the Center for Engaged Learning and professor of English: Professional Writing \& Rhetoric at Elon University. Her research examines transfer of writing knowledge and practices, multi-institutional research and collaborative inquiry, the writing lives of university students, and high-impact pedagogies. Jessie's professional service to the scholarship of teaching and learning was recognized with the 2019 International Society for the Scholarship of Teaching and Learning (ISSOTL) Distinguished Service Award. 


\section{REFERENCES}

Bernstein, D. (2013). How SoTL-active faculty members can be cosmopolitan assets to an institution. Teaching and Learning Inquiry, 1(1), 35-40. https://doi.org/10.20343/teachlearninqu.1.1. 35.

Bond, M. A., \& Blevins, S. J. (2020). Using faculty professional development to foster organizational change: A social learning framework. TechTrends, 64, 229-237. https://doi.org/10.1007/s11528-01900459-2.

Boyer, E. L. (1990). Scholarship reconsidered: Priorities of the professoriate. Stanford, California: Carnegie Foundation for the Advancement of Teaching.

Bronfenbrenner, U. (1981). The ecology of human development: Experiments by nature and design. Cambridge, MA: Harvard UP.

Bronfenbrenner, U. (1993). The ecology of cognitive development: Research models and fugitive findings. In Wozniak, R. H. \& Fischer, K. W. (Eds.), Development in context: Acting and thinking in specific environments (pp. 3-44). Erlbaum.

Bronfenbrenner, U., \& Morris, P. A. (2006). The bioecological model of human development. In Lerner, R. M. \& Damon, W. (Eds.), Handbook of child psychology: Theoretical models of human development (p. 793-828). John Wiley \& Sons Inc.

Chism, N., Holley, M., \& Harris, C. (2012). Researching the impact of educational development: Basis for informed practice. To Improve the Academy, 31, 129-145. https://doi.org/10.1002/j.2334-4822.2012. tb00678.x.

Friberg, J. (2016). Might the 4M framework support SoTL advocacy? The SoTL Advocate. https:// illinoisstateuniversitysotl.wordpress.com/2016/07/11/might-the-4m-framework-support-sotl-advocacy/.

Hannah, S. T., \& Lester, P. B. (2009). A multilevel approach to building and leading learning organizations. The Leadership Quarterly, 20, 34-48. https://doi.org/10.1016/j.leaqua.2008.11.003.

Mårtensson, K., Roxå, T., \& Stensaker, B. (2014). From quality assurance to quality practices: An investigation of strong microcultures in teaching and learning. Studies in Higher Education, 39(4), 534-545. https://doi.org/10.1080/03075079.2012.709493.

Poole, G., Iqbaul, I., \& Verwood, R. (2019). Small significant networks as birds of a feather. International Journal for Academic Development, 24(1), 61-72. https://doi.org/10.1080/1360144X.2018.1492924.

Roxå, T. (2014). Microcultures in the meso level of higher education organisations: The commons, the club, the market, and the square. (Doctoral dissertation).

Roxå, T., \& Mårtensson, K. (2009). Significant conversations and significant networks - Exploring the backstage of the teaching arena. Studies in Higher Education, 34(5), 547-559. https://doi.org/10.1080/ 03075070802597200.

Roxå, T., \& Mårtensson, K. (2012). How effects from teacher training of academic teachers propagate into the meso level and beyond. In Simon, E. \& Pleschova, G. (Eds.), Teacher development in higher education. Existing programs, program impact, and future trend. (pp. 213-233). London, UK: Routledge.

Simmons, N. (2016). Synthesizing SoTL institutional initiatives toward national impact. New Directions for Teaching and Learning, 146, 95-102. https://doi.org/10.1002/tl.20192.

Simmons, N. (2020). The 4M framework as analytic lens for SoTL's impact: A study of seven scholars. Teaching \& Learning Inquiry, 8(1), 76-90. https://doi.org/10.20343/teachlearninqu.8.1.6. 
Weston, C., Matsushita, K., Tovar, M., Berthiaume, D., Taguchi, M., \& Timmermans, J. (2008). A faculty development framework to capture the impact of our work. Panel presentation at the International Society for the Scholarship of Teaching and Learning (ISSOTL) conference, Edmonton, Canada, October 2008.

Open Access. This is an open-access article distributed under the terms of the Creative Commons Attribution-NonCommercial 4.0 International License (https://creativecommons.org/licenses/by-nc/4.0/), which permits unrestricted use, distribution, and reproduction in any medium for non-commercial purposes, provided the original author and source are credited, a link to the CC License is provided, and changes - if any - are indicated. 